\title{
The International Exports of U.S. States: An Investigation for Local Spatial Patterns
}

Chen Wu, Christian Nsiah, and Walter J Mayer*

\begin{abstract}
The new economic geography literature has broadened awareness that economic agents' geographic locations influence one another. Whereas the effect of proximity between exporting and importing units has been investigated somewhat heavily, the possible effect that neighboring economic units can have on each other's trade with other economic units only relatively recently has received much attention. Neglecting spatial correlation can produce biased estimated coefficients and, consequently, biased estimates of trade, regardless of methodology the latter is based on. Using panel data on the manufacturing exports of the 48 contiguous U.S. states to 24 Asian countries, we empirically test for local spatial linkages in the manufacturing exports of U.S. states to the Asian region. We investigate if spatial linkages are created by geographic, cultural, infrastructural, innovation asset, business environment, and economic development proximities. We find that all proximity weights generate statistically significant spatial linkages.
\end{abstract}

Key Words: Spatial Autoregressive, State Exports, Asian Export Markets, Gravity Model, Panel Data, Fixed Effects

JEL Classification Codes: F10, C23, R12

\section{INTRODUCTION}

The importance of knowledge spillovers, spatial linkages, and the spatial agglomeration in regional and international economic performance has been expounded by the new economic geography literature. The new economic geography literature has created the awareness that geographic locations influence each other. However, most trade analyses only consider the effect of proximity between exporting and importing units while ignoring the possible impact of neighboring units on each other's trade performance. As shown, for example, by Anselin and Griffith (1988), the application of standard econometric techniques in trade analysis, including the well acclaimed gravity model, may result in misleading significance tests and measures of fit in the presence of spatial correlation.

Similar levels of performance in an export market might depend not only on the proximity ${ }^{1}$ of exporting unit to export markets as depicted by standard gravity models for example, but also on the level of knowledge spillovers, industry agglomeration, or other similarities between proximate economic units, If so, then observing that economic units with similar distances to an export market perform at similar levels might also be due to other

\footnotetext{
* Wu and Nsiah are, respectively, Assistant and Associate Professors of Economics at Black Hills State University; Mayer is Associate Professor of Economics at the University of Mississippi.

Contact author: Christian Nsiah, College of Business and Technology, Black Hills State University, Unit 9064, Spearfish, SD

57783.E-mail: christiannsiah@bhsu.edu

${ }^{1}$ This distance can be physical or conceptual.
}

(C) Southern Regional Science Association 2012.

ISSN 1553-0892

SRSA, 1601 University Avenue, PO Box 6025, Morgantown, West Virginia 26506-6025, USA 
similarities shared by these economic units. Not accounting for such similarities might cause the errors to be spatially autocorrelated. ${ }^{2}$

Since 1960, Asia, the largest and most populous continent, has become richer faster than any other region of the world. This spectacular growth presents opportunities for U.S. exporters, because with the growth come increases in consumption of all goods including U.S. made goods. It is therefore of interest to investigate how proximate U.S. states have performed in this region. This study uses the manufacturing exports of the 48 U.S. states to 24 Asian countries for the years between 1998 and 2005 and tries to provide some insights to how U.S. states export performance in the Asian region are related to similarities shared by the states.

Few studies have investigated U.S. states' export patterns, and most have focused exclusively on the distance from importing countries, with only a few including Coughlin (2004) considering other spatial issues such as regional trade agreements. To better characterize the structure of U.S. state's international export patterns, this study employs a spatial autoregressive gravity model with fixed effects to investigate the presence of local spatial linkages in states' high-technology, low-technology, and total exports.

Spatial econometrics has its roots in the study of geography, so naturally trade investigations that apply spatial econometrics typically use physical geographic notions of distance in their spatial model specifications. However, there is no inherent reason for spatial distance to be limited to geographic or Euclidean distance. Although "proximity" means closeness, one needs to take note that it does not necessarily imply only physical closeness.

Proximity can take on a variety of dimensions besides the obvious candidate distance, including cultural, institutional, ${ }^{3}$ ecological, economic, regional, and political. ${ }^{4}$ It is possible that different spatial phenomenon may play different roles in determining economic performance, depending on the definition of economic performance. For instance, Rodrick et al. (2002) argues that institutions trump geography in determining economic activity; Easterly and Levine (2002) argue that geography has an effect through institutions; and Sachs (2001) indicates that geography has a direct effect on economic performance.

Our contribution to the literature is threefold. First, we introduce four new categories of proximity indices in addition to the traditional geographical one, including economic institutions, culture, infrastructure, business environment, human development, and innovation assets. Our results are more comprehensive than previous studies since we consider spatial linkages in U.S. states' exports through several aspects of proximity. The use of physical distances partly builds on what Krugman (1991a) has termed the core-periphery problem. In our case, this is to investigate whether concentration of trade activity has relatively strong effect in raising surrounding regions trade activity to similar levels. Second, we employ the more sophisticated spatial autoregressive gravity model with fixed effects to investigate the presence of local spatial linkages through the dependent variables as well as the error terms. To the best of our

\footnotetext{
${ }^{2}$ An application of the "first law of geography" can also be seen in Can (1998), where spatially correlated errors indicate the similarity in the prices of homes that are proximate because they share similar features that are not explicitly included in the regression equation.

${ }^{3}$ Rodrik, Subramanian, and Trebi (2002) argue that institutions "trump” both trade and geography in explaining income difference.

${ }^{4}$ Acemoglu, Johnson, and Robinson (2001) argue that colonial institutions affect economic performance
} 
knowledge, allowing spatial linkages simultaneously through both types of channels has not been done previously in the trade literature. Third, we differentiate the spatial correlation in the state's high-technology and low-technology exports to the Asian region as we believe that the proximity may play different roles in these two types of exports.

The rest of this paper is organized as follows. Section 2 describes the empirical methodology and data employed by this study. Section 3 presents the results from the estimations, and conclusions drawn from the results.

\section{ESTIMATION APPROACH}

This study estimates a spatial autoregressive gravity model with fixed effects to capture spatial correlations in export markets across US states. The gravity model is specified for exports from the 48 states to 24 Asian countries for the years between 1998 and 2004. Due to the capacities of available econometric software packages, only 24 Asian countries are included for this study (see the appendix for a list). Data definitions and descriptive statistics are presented in Table 1.

\subsection{Gravity Model}

In the international trade literature, the gravity model was developed by Tinbergen (1962), Pöyhönen (1963), and Linnemann (1966). It has been widely used and has achieved empirical success in explaining various types of trade between economic entities. In the gravity model, the volume of trade is assumed to be an increasing function of the national income and population of the trading partners and a decreasing function of the distance between them. It is a general equilibrium model specified as a log-linear relationship.

Table 1: Data Definitions, Descriptive Statistics and Sources of Data

\begin{tabular}{|c|c|c|c|c|c|c|}
\hline Variables & Description & Mean & Std. Dev & Min & Max & Source \\
\hline $\begin{array}{l}\text { Total } \\
\text { Exports }\end{array}$ & $\begin{array}{l}\text { Total Manufacturing } \\
\text { exports value from } \\
\text { each state to each } \\
\text { country (U.S. \$) }\end{array}$ & $107,761,352$ & $347,354,179$ & 0 & $6,410,480,734$ & $\begin{array}{l}\text { World Institute for } \\
\text { Strategic Economic } \\
\text { Research }\end{array}$ \\
\hline High-tech & $\begin{array}{l}\text { High-tech exports } \\
\text { (U.S. \$) }\end{array}$ & $74,235,239$ & $269,007,281$ & 0 & $6,379,347,798$ & $\begin{array}{l}\text { World Institute for } \\
\text { Strategic Economic } \\
\text { Research }\end{array}$ \\
\hline Low-tech & $\begin{array}{l}\text { Low-tech exports } \\
\text { (U.S. \$) }\end{array}$ & $33,526,112$ & $161,663,786$ & 0 & $4,130,751,639$ & $\begin{array}{l}\text { World Institute for } \\
\text { Strategic Economic } \\
\text { Research }\end{array}$ \\
\hline $\begin{array}{l}\text { Country } \\
\text { GDP }\end{array}$ & $\begin{array}{l}\text { Country Real Gross } \\
\text { Domestic Product } \\
\text { (Constant } 2000 \\
\text { Million U.S. \$) }\end{array}$ & $347,402.44$ & $844,583.22$ & 550 & $4,205,410$ & $\begin{array}{l}\text { World Development } \\
\text { Indicators }\end{array}$ \\
\hline $\begin{array}{l}\text { Country } \\
\text { Population }\end{array}$ & Country Population & $141,481,364$ & $310,364,874$ & 310,525 & $1,291,001,804$ & $\begin{array}{l}\text { World Development } \\
\text { Indicators }\end{array}$ \\
\hline State GDP & $\begin{array}{l}\text { Real GDP by state } \\
\text { (Millions of chained } \\
2000 \text { U.S. \$) }\end{array}$ & $232,450.55$ & $266,933.85$ & 18,084 & $1,622,000$ & $\begin{array}{l}\text { US Bureau of } \\
\text { Economic Analysis }\end{array}$ \\
\hline $\begin{array}{l}\text { State } \\
\text { population }\end{array}$ & State Population & $5,845,484.1$ & $6,239,398.8$ & 479,602 & $35,629,666$ & US Census Bureau \\
\hline
\end{tabular}


As argued in Chen and Wall (2005), there may be some unobserved factors that are correlated with the gravity variables and affect the level of trade. Without controlling for such heterogeneity, the gravity model will suffer from estimation bias (Chen and Wall, 2005). To deal with this possible heterogeneity, we follow Coughlin and Wall $(2003,2005)$ by using a statecountry fixed effects gravity model. This also avoids the problem of choosing the appropriate measure of distance, which has been an issue in the literature (c.f. Head and Mayer, 2002).

Spatial correlation is another key issue we address. As Tobler (1970) states "everything is related to everything else but near things are more related than distant things.” Essentially, space is important in economic investigations. In spatial econometric models, cross-sectional units are related through correlated dependent variables (spatial autocorrelation) and correlated disturbances (spatial heterogeneity). For two states competing in an export market, for example, export performance may be correlated because of similar cultures, business environments, government policies, close geographical proximity and other possibly unobserved factors.

To allow for both types of spatial correlation as well as correlation between the unobserved state-country-pair heterogeneity and the regressors, we adopt the following spatialautoregressive fixed-effects version of the gravity equation:

(1a) $\ln \left(1+x_{i j t}^{k}\right)=\alpha_{i j}^{k}+\lambda^{k} \mathbf{W} \ln \left(1+x_{i j t}^{k}\right)+\beta_{1}^{k} \ln Y_{i t}+\beta_{2}^{k} \ln Y_{j t}+\beta_{3}^{k} \ln N_{i t}+\beta_{4}^{k} \ln N_{j t}+u_{i j t}^{k}$

(1b) $u_{i j t}^{k}=\rho^{k} \mathbf{M} u_{i j t}^{k}+v_{i j t}^{k}$

where $x_{i j t}^{k}$ is real exports of type k (high-tech, low-tech or total exports) from state $i$ to country $j$ in year $t, \alpha_{i j}^{k}$ is the "state-country pair" heterogeneity between the trading partners including the effects of all time-invariant variables such as distance, contiguity, language, and other immeasurable factors; $\mathbf{W}$ is an $n \times n$ nonstochastic spatial weight matrix that generates the spatial dependence on the exports of other states. Similarly, $\mathbf{M}$ is an $n \times n$ weight matrix for the disturbances. In all of our applications we set $\mathbf{W}=\mathbf{M}$. The variable $Y_{i t}$ is the real gross state product (GSP) of state $i$ in year $t, Y_{j t}$ is the real GDP of country $j$ in year $t, N_{i t}$ is the population of state i in year $\mathrm{t}, N_{j t}$ is the population of country $j$ in year $t$, and $u_{i j t}^{k}$ and $v_{i j t}^{k}$ are random error terms. The parameters $\lambda^{k}$ and $\rho^{k}$ represent the spatial correlations between the dependent variables and between the disturbances respectively. Positive spatial correlation in the neighboring states' export performance exists if $\lambda^{k}>0$, negative spatial correlation exists if $\lambda^{k}<$ 0 , and no spatial correlation exists if $\lambda^{k}=0$. Similarly, positive $\rho^{k}$ indicates positive spatial correlation in the error terms, negative $\rho^{k}$ means negative correlation, and there is no spatial correlation with $\rho^{k}=0$.

Equation (1) is a spatial autoregressive panel with fixed effects and spatial autoregressive disturbances. A convenient transformation estimation approach for models of this type has recently been proposed by Lee and Yu (2010). Following Lee and Yu (2010), we apply a Helmert transformation ${ }^{5}$ to Equation (1) to eliminate heterogeneity. The transformation entails for each of the first $(T-1)$ observations, subtracting the mean of the remaining future observations available in the sample $(T=1 \ldots 8)$. The observations in the last year, 2005, are dropped after the transformation. The transformed Equation (1) then is estimated using the generalized spatial two-stage least squares estimator. Because some observations of state exports

\footnotetext{
${ }^{5}$ For the details of Helmert transformation, see Arellano and Bover (1995).
} 
are zero, we follow both Eichengreen and Irwin (1998) and Coughlin and Wall (2003) and specify the dependent variable as the natural log of $(1+$ exports).

\subsubsection{Dependent Variables (Export Performance)}

The dependent variable for this study is "export performance," which is defined as the manufacturing export of type $k$ from state $i$ to country $j$. The export data are from the Origin of Movement (OM) series from the World Institute for Strategic Economic Research (WISER). The OM series allocates exports to states on the basis of state of transportation origin. The reliability of this series is considered to be good for manufactured exports. However, it has been criticized for overstating exports of bulk commodities, such as grain, from states with large ports. ${ }^{6}$ In view of this criticism we confined our sample to manufacturing exports. Agricultural exports are excluded because of the inherent bias of the OM state export data series, which allocates most agricultural exports to states with large seaports even when there is no significant documented agriculture production in those states.

Using the North American Industry Classification System (NAICS), we disaggregated total manufacturing exports into high-tech and low-tech manufacturing exports. To break down the industries, we adopted the revised 2007 version of high-technology industry NAICS codes converted by The U.S. Department of Commerce and Office of Technology Policy from the list of high-technology SIC codes, which was identified by The Bureau of Labor Statistics (BLS) in 1999 based on measures of industry employment in both R\&D and technology-oriented occupations. The high-tech industries include petroleum refineries, electronic goods and equipment, industrial machinery manufacturing, etc. The remaining exports are classified as lowtech exports. Some of the significant industries classified as low-tech are furniture and fixtures, leather and leather products, plastics and rubber, and the apparel and other textile industries.

\subsubsection{Gross Domestic Product}

The gross state product (GSP) of state $i$, the gross domestic product (GDP) of country $j$, and their respective populations are used in gravity equation to indicate the mass or the size of the two entities involved in trade. The country level GDP and state GSP are obtained from the World Development Indicators and the Bureau of Economic Analysis (BEA) respectively.

New economic geography (NEG) models which allow for monopolistic competition, increasing returns to scale and transport costs, suggest the existence of a "local market effect," which may lead to economies of scale. This means that larger economies will experience cost reductions and thereby obtain a comparative advantage resulting in higher exports. Following Krugman (1991b) we hypothesize that the size of the market will have much more impact on industries with high economies of scale and also labor intensive manufacturing industries such as the low-tech industries. If the coefficient estimates for state GDP and population are negative or insignificant then our results may indicate that U.S. exports are largely from capital intensive such as the high-tech industries and low economies of scale industries.

Dhar and Panagariya (1994) show the possibility for a state's GDP growth to have a negative effect on trade. If foreign demand for the state's exports is sufficiently low, then an

\footnotetext{
${ }^{6}$ See http://www.census.gov/foreign-trade/aip/elom.html\#om.
} 
increase in output may lead to a decline in market prices of export goods causing a reduction in the trade value even with rising quantity of exports.

\subsubsection{Population}

In gravity models the impact of the population of the exporting state and the importing country can be negative or positive. A large economy may promote divisions of labor and economies of scale in production, which will lead to a comparative advantage and increased exports. On the other hand, a large domestic economy may have a large domestic market, which leads to higher level of self-sufficiency and less trade (see Martinez-Zarzoso and NowakLehmann, 2003). The data on country and state population are obtained from the World Development Indicators and the Census Bureau, respectively.

\subsection{Proximity Matrices}

The spatial linkages or proximities of observations are captured by the spatial weight matrix in equation (1). The spatial weight matrix represents the strength of the potential interaction between locations. Each weight matrix $(W)$ contains elements $w_{i j}$ that correspond to the proximity between state $i$ and state $j$. Proximity can be due to similarity of location or attributes (Goodchild, 1986) in a variety of dimensions including cultural, ecological, developmental, economic, and regional. As noted by Eff (2004b), different types of similarities can be measured in different ways. For example, geographical proximity can be broken into contiguity or great-circle distances. In view of this, we specify 15 proximity weight matrices for equation (1) including two geographical, three cultural, three infrastructural, four business environment, two investment, and a human development proximity index. A proximity effect is present when neighboring states influence each other's trade performance, share values or heritage (Eff, 2004a), or when the value of each state's exports is determined by some other variable that is itself spatially correlated. ${ }^{7}$ In our case, we examine whether the export performance of a state is directly or indirectly affected by the export performance of proximate states. The existence of such a relationship would be consistent with the Krugman-type externality in production argument.

\subsubsection{Geographical Proximity}

We employ two geographical proximity weight matrices, one based on contiguity (adjacency) and the other on geographical distance. The latter can be measured by travel time, or derived from a multidimensional scaling analysis (Gatrell, 1989). We employ distance calculations between states based on the great-circle distance, calculated from population centers of each pair of states. The great-circle distance in kilometers between each pair of states is calculated as follows:

$$
d_{i j}=6371.1 \operatorname{arcos}\left[\sin \left(y_{i}\right) \sin \left(y_{j}\right)+\cos \left(y_{i}\right) \cos \left(y_{j}\right) \cos \left(x_{i}-x_{j}\right)\right],
$$

where $y_{i}$ is the latitude in radians for state $i, x_{i}$ is the longitude in radians for state $i$, and the subscript $j$ refers to the same measures for state $j$. The calculated distances are then converted to proximity values using the following formula:

\footnotetext{
${ }^{7}$ Note that Greenaway and Milner (1986), in a discussion of gravity-type analysis, point out that the models face the problem that countries with similar per capita incomes tend to be clustered geographically.
} 
(3) $w_{i j}=\left(\begin{array}{cc}1+0.001 d_{i j} & \text { for } i \neq j \\ 0 & \text { for } i=j\end{array}\right.$

To standardize this matrix, each element $w_{i j}$ is divided by $\max _{j} w_{i j}$ so that the resulting elements range from zero to one.

The other approach we employ uses a contiguity matrix based on adjacency. Contiguity modeling is often used when states with shared borders are deemed proximate. A standard approach is to specify the $i, j$-th element of the spatial weight matrix as the value of the binary indicator, $I[i, j$ adjacent $]$, where pairs of states $i, j$ are defined to be adjacent when they share common borders or a small body of water. Self-proximities are excluded and the diagonal elements are set to zero. However, this binary approach has been criticized for not differentiating the strength of spatial linkages between adjacent locations. That is to say, sparsely populated borders will bear the same weight as long and densely populated borders. ${ }^{8}$ Therefore, we adopt a distance-weighted contiguity matrix, in which the closer neighboring states are assigned (i.e. the states sharing border) larger weights than others using the distance between the population centers of states as the weight. The $i, j$-th element is $w_{i j}=\left(1+d_{i j}\right) I[i, j$ adjacent $]$.

We next consider proximities based on non-geographical distances. Proximity indices were specified that measure similarities based on culture, infrastructure, innovation assets, and business environment and economic development.

\subsubsection{Cultural Similarity}

Many studies including Clark (1946) indicate that the culture and values of a society help determine the types and magnitude of economic activity experiences. Thus, it is reasonable to assume that salient differences in state cultures and values can give rise to differences in state export performance levels. There are several variables that may influence a society's culture. To create a more inclusive cultural index, we employ eight variables that may proxy culture including high school attainment rate, college attainment rate, state and local financial support for higher education per full time student, religious diversity, percent residents that are foreign born, crime rate, ethnic fragmentation, and conservative index. ${ }^{9}$ It would have been interesting to investigate the different spatial impacts of each variable used to proxy culture. However, due to the very high correlation between them, we are unable to use all of them in the same regression. Furthermore, simultaneously running separate regressions with each one of them may lead to serious omitted variables bias concerns. Consequently, we revert to factor analysis to help determine common factors amongst our eight cultural variables to help create indices of culture for our analysis. Our factor analysis exercise reveals three cultural factors. We use these factors to create three composite cultural indices (CULT1 CULT2 CULT3) which range from 0 to 100. The variables that contribute the most to the variance in CULT1 include crime rate and racial fragmentation, whereas college attainment rate, percent of residents that are foreign-born, and conservativeness contributes the most to CULT2. For CULT3, the main variable that explains the variance in this index is religious diversity.

\footnotetext{
${ }^{8}$ See Eff (2004a) and Cliff and Ord (1973, 1981).

${ }^{9}$ The description and sources of these cultural variables will be provided by the contact author upon request.
} 


\subsubsection{Infrastructure Similarity}

Using an augmented gravity model for European countries Bougheas, Demetriades, and Morgenroth (1999) show that infrastructure proximity positively impacts the volume of trade between trading partners. In this spirit, we investigate whether infrastructure proximity between states leads to similar export performances. As in the case of culture, to construct broad indices for similarity in the availability and quality of infrastructure for states, we employ factor analysis on infrastructure variables including highway density, the availability of a containerized port, highway deficiency, urban mass transit availability, and digital infrastructure. The factor analysis procedure yields two factors and again we use the two factors to create two distinct infrastructure weight matrices (INFR1 and INFR2). The variables that contribute the most to INFR1 include containerized ports and mass transit availability whereas highway deficiency and digital infrastructure explains the variation in INF2.

\subsubsection{Innovation Assets Similarity}

We incorporate a broad array of innovation asset variables to proxy innovative activities within states. The investment variables employed include the number of Ph.D. scientists and engineers, science and engineering graduate students, percent of households with computers, university research and development expenditures, federal research and development within a states, private research and development expenditures, royalties, and patents originated from each states. We use factor analysis once again to combine these variables to form meaningful indices. Our factor analysis yields two factors. We use these two factors to derive two innovation asset indicators (PRINA, and PUINA). The variation in PRINA is mostly explained by private research and development expenditures, patents, and the percent of households with computers in the household, thus signifying private innovative assets. The variation in PUINA on the other hand is explained by the number of Ph.D. scientists and engineers, university research and development investments, and federal research and development spending in the states. The variables that explain the variation in PUINA indicates that this index represents public innovative assets.

\subsubsection{Business Environment and Economic Development Similarity}

Numerous studies, including Mitchneck (1995), Hopcroft (1997), and Goldstone (1988) indicate that local conditions and central forces influence economic development initiatives, and that economic development is accompanied by regular and predictable changes in economic institutions. Thus, states at a similar level of development may have similar types and levels of economic institutions. These institutions may affect a myriad of economic indicators including economic growth and trade. To investigate the role of business environment in determining state export performance, we employ several business environment variables including traded sector strength, percent business closings, number of new companies, percent new job growth, number of technological companies, manufacturing union density, energy cost, average hourly pay, pollution abatement cost, and litigation cost index. Using factor analysis we are able to deduce four business environment indices (BUSE1, BUSE2, BUSE3, and BUSE4). The variation in BUSE1 is mostly explained by average hourly pay, strength of the traded sector, and manufacturing union density, whereas the variation in BUSE2 is mostly explained by the number of new companies and percent business closings. BUSE3 is driven by energy costs, and the number of technological companies, whereas pollution abatement costs and new job growth 
explains most of the variation in BUSE4. To proxy economic development, we employ the human development index (HDI) from the Social Science Research Council.

\subsubsection{Weight Matrices for Non-geographical Distance Proximity Indices}

Following Eff (2004a), weight matrices for these indices were created according to the following formula: $w_{i j}=\left(1+d_{i j}\right)^{-2}$, where $d_{i j}=\left|x_{i t}-x_{j t}\right|$ and $x_{i t}$ and $x_{j t}$ denote values of proximity index of type $t$ for states $i$ and $j$ respectively. The resulting weight matrices were then rowstandardized by dividing each element by the largest element in its matrix.

\section{RESULTS}

\subsection{Gravity Model}

Table 2 reports the estimated coefficients for the gravity models. The results do not greatly differ from our expectations across all models. For the fixed-effects model without spatial correction (the first row of Table 2), the positive and statistically significant coefficient for the GDP of the importing country suggests that countries with higher incomes (measured as GDP) have stronger demand for U.S. imports. Further, the positive and significant coefficient for the population of the importing country, indicates that larger countries import more from the U.S. In contrast, the coefficients for state GSP and population are negative and significant, which may mean that size does not translate into better state export performance. This result might also reflect that American exports are largely not labor-intensive, not from industries with high economies of scale, or a "mixed bag" situation in which some larger states are not exporting much because they are self-sufficient, as shown in Martinez-Zarzoso and Nowak-Lehmann (2003). In an earlier study that uses a similar gravity model, Nsiah, Wu and Mayer (2012) also investigate the determinants of state exports performance in Asia. In that piece, we do so without taking into account the effect proximate states may have upon each other's export performance. Further, in that prior work we did not distinguish between high- and low-tech exports. Comparing the results of the present to the previous study for total exports, we find that after controlling for space, the apparent impact of the economic size of importing countries becomes larger, and the sign of the importing country's population becomes both positive and significant. Also the impact of the economic size and the population of the exporting state changes to a negative (and significant) impact on state exports, indicating self sufficiency or negative agglomeration effects.

Comparing the estimated coefficients for high-tech goods against low-tech equivalents, the magnitudes are always larger for low-tech, except for state population for which its importance is larger for high-tech goods. The larger coefficient indicates that the negative effect of state population on exports is much larger for high-tech than for low-tech products. Correcting for spatial autocorrelation does not change the signs of the coefficients but does change their size and statistical significance with several becoming insignificant. The only variable that remains significant in most models is the country GDP.

\subsection{The Impact of Different Spatial Weight Matrices}

As shown in the Table 3, we find strong evidence of spatial autocorrelation and spatial heterogeneity in our gravity models for all specifications of the weight matrices. Of the fourteen weight matrices used, all the estimates of $\rho$ are statistically significant at the one percent level, except for the state high-tech export model with weight BUSE3, which is significant at five 
Table 2: Estimated Coefficients for the Gravity Model

\begin{tabular}{|c|c|c|c|c|c|c|c|c|c|c|c|c|c|c|c|}
\hline \multirow[b]{2}{*}{ Models } & \multicolumn{5}{|c|}{ High Tech } & \multicolumn{5}{|c|}{ Low Tech } & \multicolumn{5}{|c|}{ Total Exports } \\
\hline & CGDP & CPOP & SGDP & SPOP & Intercept & CGDP & CPOP & SGDP & SPOP & Intercept & CGDP & CPOP & $S G D P$ & SPOP & Intercept \\
\hline FE Gravity Model & $\begin{array}{l}2.627 * * * \\
(0.749)\end{array}$ & $\begin{array}{l}3.368^{*} \\
(1.964)\end{array}$ & $\begin{array}{l}-2.00^{*} \\
(1.467)\end{array}$ & $\begin{array}{l}-5.219 \text { *** } \\
(1.960)\end{array}$ & $\begin{array}{l}0.201 * * \\
(0.083)\end{array}$ & $\begin{array}{l}6.297 * * * \\
(0.834)\end{array}$ & $\begin{array}{l}8.298^{* * *} \\
(2.232)\end{array}$ & $\begin{array}{l}-2.901^{*} \\
(1.641)\end{array}$ & $\begin{array}{l}3.460 \\
(2.248)\end{array}$ & $\begin{array}{l}0.297 * * * \\
(0.092)\end{array}$ & $\begin{array}{l}6.386^{* * *} \\
(0.774)\end{array}$ & $\begin{array}{l}\text { 5.438*** } \\
(1.975)\end{array}$ & $\begin{array}{l}-2.358 \\
(1.490)\end{array}$ & $\begin{array}{l}-5.750 * * * \\
(1.984)\end{array}$ & $\begin{array}{l}0.250 \text { *** } \\
(0.085)\end{array}$ \\
\hline \multicolumn{16}{|c|}{ Geographical Proximity } \\
\hline Physical Distance & $\begin{array}{l}2.173^{* * *} \\
(0.803)\end{array}$ & $\begin{array}{l}1.824 \\
(1.443)\end{array}$ & $\begin{array}{l}-0.080 \\
(1.462)\end{array}$ & $\begin{array}{l}-4.614^{* *} \\
(1.869)\end{array}$ & $\begin{array}{l}0.072 \\
(0.058)\end{array}$ & $\begin{array}{l}2.256^{* * *} \\
(0.845)\end{array}$ & $\begin{array}{l}3.341^{*} \\
(1.816)\end{array}$ & $\begin{array}{l}-0.796 \\
(1.615)\end{array}$ & $\begin{array}{l}-3.149 \\
(2.090)\end{array}$ & $\begin{array}{l}0.092 \\
(0.066)\end{array}$ & $\begin{array}{l}2.002^{* * *} \\
(0.765)\end{array}$ & $\begin{array}{l}2.266 \\
(1.508)\end{array}$ & $\begin{array}{l}0.750 \\
(1.495)\end{array}$ & $\begin{array}{l}-4.843^{* * *} \\
(1.870)\end{array}$ & $\begin{array}{l}0.780 \\
(0.059)\end{array}$ \\
\hline Contiguity & $\begin{array}{l}4.404^{* * *} \\
(1.082)\end{array}$ & $\begin{array}{l}2.479 \\
(1.811)\end{array}$ & $\begin{array}{l}1.366 \\
(1.583)\end{array}$ & $\begin{array}{l}4.047^{* *} \\
(1.902)\end{array}$ & $\begin{array}{l}0.146^{* *} \\
(0.075)\end{array}$ & $\begin{array}{l}3.512^{* * *} \\
(1.071)\end{array}$ & $\begin{array}{l}4.655^{* *} \\
(2.113)\end{array}$ & $\begin{array}{l}-1.760 \\
(1.681)\end{array}$ & $\begin{array}{l}-1.892 \\
(2.117)\end{array}$ & $\begin{array}{l}0.165^{* *} \\
(0.081)\end{array}$ & $\begin{array}{l}4.096^{* * *} \\
(1.043)\end{array}$ & $\begin{array}{l}3.634^{* *} \\
(1.878)\end{array}$ & $\begin{array}{l}-1.446 \\
(1.592)\end{array}$ & $\begin{array}{l}-4.211^{* *} \\
(1.904)\end{array}$ & $\begin{array}{l}0.166^{* *} \\
(0.075)\end{array}$ \\
\hline \multicolumn{16}{|l|}{ Cultural Proximity } \\
\hline CULT 1 & $\begin{array}{l}2.380^{* *} \\
(0.936)\end{array}$ & $\begin{array}{l}1.875 \\
(1.437)\end{array}$ & $\begin{array}{l}-0.967 \\
(1.532)\end{array}$ & $\begin{array}{l}-3.247^{*} \\
(1.815)\end{array}$ & $\begin{array}{l}0.070 \\
(0.056)\end{array}$ & $\begin{array}{l}0.686 \\
(0.961)\end{array}$ & $\begin{array}{l}1.115 \\
(1.707)\end{array}$ & $\begin{array}{l}-0.892 \\
(1.606)\end{array}$ & $\begin{array}{l}-0.346 \\
(1.837)\end{array}$ & $\begin{array}{l}0.010 \\
(0.051)\end{array}$ & $\begin{array}{l}2.342 * * * \\
(0.888)\end{array}$ & $\begin{array}{l}2.596 * \\
(1.552)\end{array}$ & $\begin{array}{l}-0.863 \\
(1.535)\end{array}$ & $\begin{array}{l}-3.907 * * \\
(1.822)\end{array}$ & $\begin{array}{l}0.087 \\
(0.057)\end{array}$ \\
\hline CULT 2 & $\begin{array}{l}2.842^{* * * *} \\
(0.981)\end{array}$ & $\begin{array}{l}2.462 \\
(1.545)\end{array}$ & $\begin{array}{l}-1.310 \\
(1.521)\end{array}$ & $\begin{array}{l}-4.415^{* *} \\
(1.905)\end{array}$ & $\begin{array}{l}0.064 \\
(0.065)\end{array}$ & $\begin{array}{l}1.303 \\
(0.997)\end{array}$ & $\begin{array}{l}2.107 \\
(1.908)\end{array}$ & $\begin{array}{l}-1.182 \\
(1.695)\end{array}$ & $\begin{array}{l}-1.348 \\
(2.095)\end{array}$ & $\begin{array}{l}0.036 \\
(0.067)\end{array}$ & $\begin{array}{l}2.545^{* * *} \\
(0.925)\end{array}$ & $\begin{array}{l}3.075 * \\
(1.597)\end{array}$ & $\begin{array}{l}-1.459 \\
(1.550)\end{array}$ & $\begin{array}{l}-4.249^{* *} \\
(1.897)\end{array}$ & $\begin{array}{l}0.066 \\
(0.064)\end{array}$ \\
\hline CULT 3 & $\begin{array}{l}2.212^{* *} \\
(1.119)\end{array}$ & $\begin{array}{l}1.917 \\
(1.815)\end{array}$ & $\begin{array}{l}-1.374 \\
(1.544)\end{array}$ & $\begin{array}{l}-2.988 \\
(1.980)\end{array}$ & $\begin{array}{l}0.043 \\
(0.078)\end{array}$ & $\begin{array}{l}1.775^{*} \\
(1.077)\end{array}$ & $\begin{array}{l}2.815 \\
(2.070)\end{array}$ & $\begin{array}{l}-1.698 \\
(1.670)\end{array}$ & $\begin{array}{l}-1.289 \\
(2.130)\end{array}$ & $\begin{array}{l}0.055 \\
(0.074)\end{array}$ & $\begin{array}{l}2.007^{* *} \\
(0.986)\end{array}$ & $\begin{array}{l}2.392 \\
(1.693)\end{array}$ & $\begin{array}{l}-1.480 \\
(1.562)\end{array}$ & $\begin{array}{l}-2.915 \\
(1.914)\end{array}$ & $\begin{array}{l}0.045 \\
(0.068)\end{array}$ \\
\hline \multicolumn{16}{|c|}{ Infrastructure Proximity } \\
\hline INFRA 1 & $\begin{array}{l}0.698 \\
(0.757)\end{array}$ & $\begin{array}{l}0.688 \\
(1.060)\end{array}$ & $\begin{array}{l}-0.454 \\
(1.306)\end{array}$ & $\begin{array}{l}-1.376 \\
(1.596)\end{array}$ & $\begin{array}{l}0.010 \\
(0.040)\end{array}$ & $\begin{array}{l}0.723 \\
(0.999)\end{array}$ & $\begin{array}{l}1.235 \\
(1.935)\end{array}$ & $\begin{array}{l}0.358 \\
(1.662)\end{array}$ & $\begin{array}{l}-2.500 \\
(1.942)\end{array}$ & $\begin{array}{l}0.045 \\
(0.065)\end{array}$ & $\begin{array}{l}0.769 \\
(0.776)\end{array}$ & $\begin{array}{l}0.975 \\
(1.233)\end{array}$ & $\begin{array}{l}-0.135 \\
(1.403)\end{array}$ & $\begin{array}{l}-2.227 \\
(1.587)\end{array}$ & $\begin{array}{l}0.024 \\
(0.430)\end{array}$ \\
\hline INFRA 2 & $\begin{array}{l}2.383^{* * *} \\
(0.897)\end{array}$ & $\begin{array}{l}2.229 \\
(1.517)\end{array}$ & $\begin{array}{l}-1.017 \\
(1.490)\end{array}$ & $\begin{array}{l}-4.187 * * \\
(1.892)\end{array}$ & $\begin{array}{l}0.542 \\
(0.631)\end{array}$ & $\begin{array}{l}0.558 \\
(0.906)\end{array}$ & $\begin{array}{l}0.917 \\
(1.729)\end{array}$ & $\begin{array}{l}-0.321 \\
(1.595)\end{array}$ & $\begin{array}{l}-1.078 \\
(1.966)\end{array}$ & $\begin{array}{l}0.010 \\
(0.057)\end{array}$ & $\begin{array}{l}2.375^{* * *} \\
(0.867)\end{array}$ & $\begin{array}{l}2.954^{*} \\
(1.602)\end{array}$ & $\begin{array}{l}-1.094 \\
(1.518)\end{array}$ & $\begin{array}{l}-4.493^{* *} \\
(1.899)\end{array}$ & $\begin{array}{l}0.069 \\
(0.064)\end{array}$ \\
\hline \multicolumn{16}{|l|}{$\underline{\text { Innovation Assets }}$} \\
\hline Private & $\begin{array}{l}0.924 \\
(0.843)\end{array}$ & $\begin{array}{l}0.994 \\
(1.319)\end{array}$ & $\begin{array}{l}-0.304 \\
(1.412)\end{array}$ & $\begin{array}{l}-2.159 \\
(1.854)\end{array}$ & $\begin{array}{l}0.018 \\
(0.050)\end{array}$ & $\begin{array}{l}0.935 \\
(0.764)\end{array}$ & $\begin{array}{l}1.642 \\
(1.379)\end{array}$ & $\begin{array}{l}-0.886 \\
(1.340)\end{array}$ & $\begin{array}{l}-1.173 \\
(1.008)\end{array}$ & $\begin{array}{l}0.023 \\
(0.020)\end{array}$ & $\begin{array}{l}2.196 * * \\
(0.888)\end{array}$ & $\begin{array}{l}2.825^{*} \\
(1.619)\end{array}$ & $\begin{array}{l}-1.565 \\
(1.522)\end{array}$ & $\begin{array}{l}-3.536 * \\
(1.902)\end{array}$ & $\begin{array}{l}0.052 \\
(0.060)\end{array}$ \\
\hline Public & $\begin{array}{l}2.031^{* *} \\
(0.864)\end{array}$ & $\begin{array}{l}1.810 \\
(1.269)\end{array}$ & $\begin{array}{l}-0.467 \\
(1.457)\end{array}$ & $\begin{array}{l}-4.019 * * \\
(1.826)\end{array}$ & $\begin{array}{l}0.058 \\
(0.049)\end{array}$ & $\begin{array}{l}1.008 \\
(0.953)\end{array}$ & $\begin{array}{l}1.667 \\
(1.844)\end{array}$ & $\begin{array}{l}-0.810 \\
(1.673)\end{array}$ & $\begin{array}{l}-1.328 \\
(1.961)\end{array}$ & $\begin{array}{l}0.017 \\
(0.053)\end{array}$ & $\begin{array}{l}0.845 \\
(0.797)\end{array}$ & $\begin{array}{l}1.158 \\
(1.279)\end{array}$ & $\begin{array}{l}-0.181 \\
(1.456)\end{array}$ & $\begin{array}{l}-2.462 \\
(1.699)\end{array}$ & $\begin{array}{l}0.017 \\
(0.041\end{array}$ \\
\hline \multicolumn{16}{|c|}{ Business Environment and Economic Development } \\
\hline BUSE 1 & $\begin{array}{l}1.850^{* *} \\
(0.818)\end{array}$ & $\begin{array}{l}1.780 \\
(1.230)\end{array}$ & $\begin{array}{l}-1.293 \\
(1.417)\end{array}$ & $\begin{array}{l}-2.649 \\
(1.829)\end{array}$ & $\begin{array}{l}0.032 \\
(0.050)\end{array}$ & $\begin{array}{l}2.750^{* * *} \\
(1.031)\end{array}$ & $\begin{array}{l}4.336^{* *} \\
(1.971)\end{array}$ & $\begin{array}{l}-2.591 \\
(1.672)\end{array}$ & $\begin{array}{l}-1.958 \\
(2.111)\end{array}$ & $\begin{array}{l}0.083 \\
(0.069)\end{array}$ & $\begin{array}{l}2.243^{* * *} \\
(0.838)\end{array}$ & $\begin{array}{l}2.814 * * \\
(1.407)\end{array}$ & $\begin{array}{l}-1.975 \\
(1.499)\end{array}$ & $\begin{array}{l}-2.957 \\
(1.834)\end{array}$ & $\begin{array}{l}0.045 \\
(0.053)\end{array}$ \\
\hline BUSE 2 & $\begin{array}{l}0.559 \\
(0.725)\end{array}$ & $\begin{array}{l}0.578 \\
(1.026)\end{array}$ & $\begin{array}{l}0.080 \\
(1.298)\end{array}$ & $\begin{array}{l}-1.870 \\
(1.673)\end{array}$ & $\begin{array}{l}0.016 \\
(0.040)\end{array}$ & $\begin{array}{l}2.102^{* *} \\
(1.010)\end{array}$ & $\begin{array}{l}2.981 \\
(1.967)\end{array}$ & $\begin{array}{l}-1.536 \\
(1.687)\end{array}$ & $\begin{array}{l}-0.985 \\
(2.089)\end{array}$ & $\begin{array}{l}0.089 \\
(0.067)\end{array}$ & $\begin{array}{l}0.871 \\
(0.771)\end{array}$ & $\begin{array}{l}1.148 \\
(1.222)\end{array}$ & $\begin{array}{l}-0.148 \\
(1.431)\end{array}$ & $\begin{array}{l}-2.566 \\
(1.683)\end{array}$ & $\begin{array}{l}0.025 \\
(0.043)\end{array}$ \\
\hline BUSE 3 & $\begin{array}{l}1.327^{*} \\
(0.792)\end{array}$ & $\begin{array}{l}1.353 \\
(1.147)\end{array}$ & $\begin{array}{l}-0.815 \\
(1.369)\end{array}$ & $\begin{array}{l}-2.791 \\
(1.789)\end{array}$ & $\begin{array}{l}0.004 \\
(0.046)\end{array}$ & $\begin{array}{l}2.846^{* * * *} \\
(1.013)\end{array}$ & $\begin{array}{l}4.349 * * \\
(1.916)\end{array}$ & $\begin{array}{l}-1.795 \\
(1.673)\end{array}$ & $\begin{array}{l}-3.025 \\
(2.087)\end{array}$ & $\begin{array}{l}0.106 \\
(0.067)\end{array}$ & $\begin{array}{l}1.386^{*} \\
(0.819)\end{array}$ & $\begin{array}{l}1.781 \\
(1.298)\end{array}$ & $\begin{array}{l}-0.564 \\
(1.436)\end{array}$ & $\begin{array}{l}-3.506^{* *} \\
(1.784)\end{array}$ & $\begin{array}{l}0.019 \\
(0.048)\end{array}$ \\
\hline BUSE 4 & $\begin{array}{l}1.576^{*} \\
(0.870)\end{array}$ & $\begin{array}{l}1.562 \\
(1.222)\end{array}$ & $\begin{array}{l}-0.627 \\
(1.405)\end{array}$ & $\begin{array}{l}-3.079 * \\
(1.761)\end{array}$ & $\begin{array}{l}0.035 \\
(0.046)\end{array}$ & $\begin{array}{l}0.841 \\
(0.998)\end{array}$ & $\begin{array}{l}1.424 \\
(1.862)\end{array}$ & $\begin{array}{l}-0.457 \\
(1.651)\end{array}$ & $\begin{array}{l}-1.441 \\
(2.023)\end{array}$ & $\begin{array}{l}0.030 \\
(0.062)\end{array}$ & $\begin{array}{l}1.312 \\
(0.834)\end{array}$ & $\begin{array}{l}1.694 \\
(1.356)\end{array}$ & $\begin{array}{l}-0.374 \\
(1.460)\end{array}$ & $\begin{array}{l}-3.052 * \\
(1.763)\end{array}$ & $\begin{array}{l}0.042 \\
(0.048)\end{array}$ \\
\hline$H D I$ & $\begin{array}{l}1.844^{* *} \\
(0.878)\end{array}$ & $\begin{array}{l}1.971 \\
(1.442)\end{array}$ & $\begin{array}{l}-0.857 \\
(1.483)\end{array}$ & $\begin{array}{l}-3.473 * \\
(1.864)\end{array}$ & $\begin{array}{l}0.039 \\
(0.056)\end{array}$ & $\begin{array}{l}0.517 \\
(0.895)\end{array}$ & $\begin{array}{l}0.938 \\
(1.777)\end{array}$ & $\begin{array}{l}-0.291 \\
(1.660)\end{array}$ & $\begin{array}{l}-0.941 \\
(1.970)\end{array}$ & $\begin{array}{l}0.019 \\
(0.056)\end{array}$ & $\begin{array}{l}0.814 \\
(0.781)\end{array}$ & $\begin{array}{l}1.181 \\
(1.361)\end{array}$ & $\begin{array}{l}-0.458 \\
(1.492)\end{array}$ & $\begin{array}{l}-1.706 \\
(1.760)\end{array}$ & $\begin{array}{l}0.020 \\
(0.047)\end{array}$ \\
\hline
\end{tabular}

Notes: FE denotes fixed-effects model. ***, **, * denotes level of significance at the $1 \%, 5 \%$ and $10 \%$ respectively. The number in parenthesis is the robust standard error. 
percent. All estimates of $\lambda$ are positive with values from 0.03 for the high-tech export with INFRA2 to 1.06 for the total export with the physical distance proximity matrix. This indicates that states "closer" in terms of proximity including geography, culture, and business environment experience similar export performance in the Asian Export market for all manufactured goods. This result may be due to the cluster effect in the export performance among the proximate states, especially in the case of physical proximity. The cluster effect in this case occurs because firms in those states can share ideas, labor force, and other resources. In the case of the nongeographical proximity, the results can be interpreted as that states with similar culture, business climate, infrastructure and innovation assets perform at similar levels in the Asian export market. Among the fourteen proximity weight matrices geographical distance generates the most prevalent spatial dependence across states for all the three types of exports. Specially, we find that a one percent point average increase in the three types of exports of the geographically proximate states will lead to a 1.018, 0.994, and 1.06 percent increase in a state's high-tech, lowtech, and total exports, respectively. These results suggest a clustering effect: physically closer states share more in production resources, technology, industry and even export-oriented business policy, which causes them to perform at similar levels in the export market.

As for the spatial correlation in the error terms, except for the case for low-tech export with private innovation and BUSE1, all estimates of in column 3, 5, and 7 of Table 3 are negative. The negative estimates indicate negative correlation between the error terms. This suggests that the changes in the errors largely reflect exogenous shocks that change relative exports across states. The estimates of are all significant except for high-tech exports with CUL3, and range from -0.019 for high-tech exports with INFRA2, to -0.929 for low-tech exports with physical distance. Similar to what was found for the spatial dependence parameter, geographical distance generates the strongest spatial correlation across the errors for all the three types of exports. This is further evidence that geographically proximate states have the greatest influence on each other's export performance. Physically closer states are linked by higher levels of knowledge spillovers, industry agglomeration, and mobility of production resources. They also likely compete more intensively for relative export shares when shocks such as Asian financial crisis occur.

Comparing the spatial impacts of all the proximity variables on the high- and low-tech exports, several interesting conclusions can be made. For 9 out of the 16 proximity matrices used, greater correlation in both the dependent variable and error terms is found for low-tech rather than high-tech exports, indicating that the states sharing similar cultural, innovative, and economic characteristics perform more similarly in the low-tech exports. Interestingly, the impact of spatial correlation for most of the business environment proximity matrices is larger for high-tech than the low-tech exports, which suggests that high-tech businesses with similar export performance tend to locate in the states with similar business environments. This result may also indicate that similar business environments generate similar institutions and business cultures which enable states to perform at similar levels in the export market. For the public innovation assets, the states with similar levels of R\&D investment, university education, and federal research spending have a stronger influence on each other's low-tech exports than hightech exports, suggesting that the general knowledge spillover matters more for low-tech industries. 
Table 3: Estimated Spatial Effects

\begin{tabular}{|c|c|c|c|c|c|c|}
\hline \multirow[b]{2}{*}{ Models } & \multicolumn{2}{|c|}{ High Tech } & \multicolumn{2}{|c|}{ Low Tech } & \multicolumn{2}{|c|}{ Total Exports } \\
\hline & Lamda & Rho & Lamda & Rho & Lamda & Rho \\
\hline \multicolumn{7}{|c|}{ Geographical Proximity } \\
\hline Physical Distance & $\begin{array}{l}1.018 * * * \\
(0.152)\end{array}$ & $\begin{array}{l}-0.818 * * * \\
(0.178)\end{array}$ & $\begin{array}{l}0.994 * * * \\
(0.147)\end{array}$ & $\begin{array}{l}-0.929 * * * \\
(0.153)\end{array}$ & $\begin{array}{l}1.060 * * * \\
(0.136)\end{array}$ & $\begin{array}{l}-0.850^{* * *} \\
(0.169)\end{array}$ \\
\hline Contiguity & $\begin{array}{l}0.275^{* *} \\
(0.123)\end{array}$ & $\begin{array}{l}-0.132 * \\
(0.072)\end{array}$ & $\begin{array}{l}0.389 * * * \\
(0.099)\end{array}$ & $\begin{array}{l}-0.205^{* * *} \\
(0.052)\end{array}$ & $\begin{array}{l}0.325^{* *} \\
(0.108)\end{array}$ & $\begin{array}{l}-0.168 * * \\
(0.063)\end{array}$ \\
\hline \multicolumn{7}{|l|}{ Cultural Proximity } \\
\hline CULT 1 & $\begin{array}{l}0.043 * * * \\
(0.009)\end{array}$ & $\begin{array}{l}-0.038 * * \\
(0.013)\end{array}$ & $\begin{array}{l}0.057 * * * \\
(0.008)\end{array}$ & $\begin{array}{l}-0.078 * * * \\
(0.012)\end{array}$ & $\begin{array}{l}0.044^{* * * *} \\
(0.008)\end{array}$ & $\begin{array}{l}-0.040 * * * \\
(0.012)\end{array}$ \\
\hline CULT 2 & $\begin{array}{l}0.041^{* * *} \\
(0.010)\end{array}$ & $\begin{array}{l}-0.027^{* *} \\
(0.013)\end{array}$ & $\begin{array}{l}0.055^{* * *} \\
(0.009)\end{array}$ & $\begin{array}{l}-0.044^{* * *} \\
(0.012)\end{array}$ & $\begin{array}{l}0.044^{* * *} \\
(0.009)\end{array}$ & $\begin{array}{l}-0.034^{* *} \\
(0.013)\end{array}$ \\
\hline CULT 3 & $\begin{array}{l}0.044^{* * * *} \\
(0.011)\end{array}$ & $\begin{array}{l}-0.011 \\
(0.015)\end{array}$ & $\begin{array}{l}0.048 * * * \\
(0.009)\end{array}$ & $\begin{array}{l}-0.037^{* *} \\
(0.013)\end{array}$ & $\begin{array}{l}0.046^{* * * *} \\
(0.009)\end{array}$ & $\begin{array}{l}-0.029 * * \\
(0.014)\end{array}$ \\
\hline \multicolumn{7}{|c|}{ Infrastructure Proximity } \\
\hline INFRA 1 & $\begin{array}{l}0.050 * * * \\
(0.005)\end{array}$ & $\begin{array}{l}-0.071 * * * \\
(0.012)\end{array}$ & $\begin{array}{l}0.049 * * * \\
(0.007)\end{array}$ & $\begin{array}{l}-0.044 * * * \\
(0.012)\end{array}$ & $\begin{array}{l}0.049 * * * \\
(0.005)\end{array}$ & $\begin{array}{l}-0.068 * * * \\
(0.012)\end{array}$ \\
\hline INFRA 2 & $\begin{array}{l}0.030 * * * \\
(0.006)\end{array}$ & $\begin{array}{l}-0.019^{*} \\
(0.011)\end{array}$ & $\begin{array}{l}0.041^{* * * *} \\
(0.005)\end{array}$ & $\begin{array}{l}-0.046^{* * * *} \\
(0.010)\end{array}$ & $\begin{array}{l}0.031 * * * \\
(0.031)\end{array}$ & $\begin{array}{l}-0.021^{*} \\
(0.011)\end{array}$ \\
\hline \multicolumn{7}{|l|}{ Innovation Assets } \\
\hline Private & $\begin{array}{l}0.043 * * * \\
(0.006)\end{array}$ & $\begin{array}{l}-0.040^{* * *} \\
(0.012)\end{array}$ & $\begin{array}{l}0.043^{* * *} \\
(0.005)\end{array}$ & $\begin{array}{l}0.585^{* * *} \\
(0.021)\end{array}$ & $\begin{array}{l}0.035^{* * *} \\
(0.006)\end{array}$ & $\begin{array}{l}-0.027 * * \\
(0.012)\end{array}$ \\
\hline Public & $\begin{array}{l}0.031^{* * *} \\
(0.005)\end{array}$ & $\begin{array}{l}-0.042 * * * \\
(0.012)\end{array}$ & $\begin{array}{l}0.037 * * * \\
(0.006)\end{array}$ & $\begin{array}{l}-0.053^{* * * *} \\
(0.011)\end{array}$ & $\begin{array}{l}0.038^{* * * *} \\
(0.005)\end{array}$ & $\begin{array}{l}-0.065^{* * *} \\
(0.012)\end{array}$ \\
\hline \multicolumn{7}{|c|}{ Business Environment and Economic Development } \\
\hline BUSE 1 & $\begin{array}{l}0.044^{* * * *} \\
(0.007)\end{array}$ & $\begin{array}{l}-0.049 * * * \\
(0.013)\end{array}$ & $\begin{array}{l}0.036 * * * \\
(0.008)\end{array}$ & $\begin{array}{l}0.039 * * * \\
(0,012)\end{array}$ & $\begin{array}{l}0.042 * * * \\
(0.007)\end{array}$ & $\begin{array}{l}-0.046^{* * *} \\
(0.012)\end{array}$ \\
\hline BUSE 2 & $\begin{array}{l}0.051^{* * * *} \\
(0.005)\end{array}$ & $\begin{array}{l}-0.078^{* * * *} \\
(0.012)\end{array}$ & $\begin{array}{l}0.039 * * * \\
(0.008)\end{array}$ & $\begin{array}{l}-0.037^{* * * *} \\
(0.011)\end{array}$ & $\begin{array}{l}0.049 * * * \\
(0.006)\end{array}$ & $\begin{array}{l}-0.071 * * * \\
(0.012)\end{array}$ \\
\hline BUSE 3 & $\begin{array}{l}0.046 * * * \\
(0.006)\end{array}$ & $\begin{array}{l}-0.060 * * * \\
(0.012)\end{array}$ & $\begin{array}{l}0.034 * * * \\
(0.008)\end{array}$ & $\begin{array}{l}-0.039 * * * \\
(0.011)\end{array}$ & $\begin{array}{l}0.046 * * * \\
(0.006)\end{array}$ & $\begin{array}{l}-0.060^{* * * *} \\
(0.012)\end{array}$ \\
\hline BUSE 4 & $\begin{array}{l}0.035 * * \\
(0.005)\end{array}$ & $\begin{array}{l}-0.046^{* * *} \\
(0.013)\end{array}$ & $\begin{array}{l}0.039 * * * \\
(0.006)\end{array}$ & $\begin{array}{l}-0.037 * * \\
(0.013)\end{array}$ & $\begin{array}{l}0.037 * * * \\
(0.005)\end{array}$ & $\begin{array}{l}-0.045^{* * * *} \\
(0.013)\end{array}$ \\
\hline$H D I$ & $\begin{array}{l}0.035^{* * *} \\
(0.006)\end{array}$ & $\begin{array}{l}-0.029 * * \\
(0.011)\end{array}$ & $\begin{array}{l}0.044^{* * *} \\
(0.005)\end{array}$ & $\begin{array}{l}-0.048^{* * *} \\
(0.011)\end{array}$ & $\begin{array}{l}0.042^{* * *} \\
(0.005)\end{array}$ & $\begin{array}{l}-0.050 * * * \\
(0.011)\end{array}$ \\
\hline
\end{tabular}

Note: Lamda and rho denote spatial correlation in the dependent variable and the error terms respectively. ***, **, * denote level of significance at the $1 \%, 5 \%$ and $10 \%$, respectively. Numbers in parentheses are the robust standard errors.

\section{CONCLUSION}

We investigated whether spatial linkages exist in U.S. state manufacturing exports to Asia. We find that without correcting for spatial linkages the estimate from the gravity model may be biased. Further, we find statistically significant spatial linkages in both the dependent variable and the error term, indicating that proximate states perform at similar levels in the Asian market. Our results reveal that geographical proximity generates the most spatial dependence in all types of exports, which is indicative of spatial agglomeration effects.

Comparing the impact of the non-geographical proximity variables, in the case of hightech exports, we find that the magnitude of the spatial linkage in the dependent variable is larger for states with similar infrastructure such as containerized ports and mass transportation, and 
similar levels of business growth. In the case of low-tech exports to Asia on the other hand, our results show that culture has the largest spatial impact: states with similar cultures experience similar levels of low-tech export performance.

Our findings, however, are limited to the Asian export market. Consequently, one direction for future research would be to investigate the presence of and the patterns of spatial linkages in U.S. state exports to other regions of the world.

\section{REFERENCES}

Acemoglu, Daron, Simon Johnson, and James A. Robinson. (2001) "The Colonial Origins of Comparative Development: An Empirical Investigation,” American Economic Review, 91, 1369-1401.

Anselin, Luc and Daniel A. Griffith. (1988) "Do Spatial Effects Really Matter in Regression Analysis?,” Papers of the Regional Science Association, 65, 11-34.

Arrellano, Manuel and Olympia Bover. (1995) "Another Look at the Instrumental Variable Estimation of Error-Component Models,” Journal of Econometrics, 68, 29-51.

Bougheas, Spiros, Panicos O. Demetriades, and Edgar L. W. Morgenroth. (1999) "Infrastructure, Transport Cost and Trade,” Journal of International Economics, 47, 169-189

Can, Ayse. (1998) “GIS and Spatial Analysis of Housing and Mortgage Markets,” Journal of Housing Research, 9, 61-86.

Chen, I.-Hui and Howard J. Wall. (2005) "Controlling for Heterogeneity in Gravity Models of Trade and Integration,” Federal Reserve Bank of St. Louis Review, 87(1), 49-63.

Clark, Warburton. (1946). “The Misplace Emphasis in Contemporary Business Fluctuation Theory,” Journal of Business, 19, 199-220.

Cliff, Andrew D. and John K. Ord. (1973) Spatial Autocorrelation. London: Pion Press. . (1981) Spatial Processes, Models, and Applications. London: Pion Press.

Coughlin, Cletus. C. (2004) “The Increasing Importance of Proximity for Exports from U.S. States,” Federal Reserve Bank of St. Louis Review, 86(6), 1-19.

Coughlin, Cletus. C. and Howard J. Wall. (2003) "NAFTA and the Changing Pattern of State Exports,” Papers in Regional Science, 82, 427-450.

Dhar, Sumana and Arvind Panagariya. (1994) "Predictions of Bilateral Trade and the Gravity Equation,” Working Paper, International Trade Division, World Bank, Washington, D.C.

Easterly, William and Rose Levine. (2002) “Topics, Germs, and Crops: How Endowments Influence Economic Development,” NBER Working Paper \# 9106. Accessed in April 2012 at http://www.nber.org/papers/w9106.pdf

Eff, E. Anthon. (2004a) "Spatial, Cultural Autocorrelation in U.S. Regional Data," MTSU Department of Economics and Finance Working Paper Series, September. Accessed in April 2012 at http://www.mtsu.edu/ berc/working/autocorrelation in US Regional data.pdf.

- (2004b) "Spatial and Cultural Autocorrelation in International Datasets," MTSU Department of Economics and Finance Working Papers. Accessed in April 2012 at http://frank.mtsu.edu/ berc/working/autocorrelation\%20in\%20US\%20regional\%20data.pdf. 
Eichengreen, Barry and Douglas A. Irwin. (1998) "The Role of History in Bilateral Trade Flows," In Jeffrey A. Frankel (ed), The Regionalization of the World Economy. University of Chicago Press: Chicago, pp. 33-62.

Gatrell, Anthony C. (1989) "On the Spatial Representation and Accuracy of Addressed-base Data in U.K.," International Journal of Geographical Information Systems, 3, 335-348.

Goldstone, Jack (1988) "Regional Ecology and Agrarian Change in England and France, 15001700," Politics and Society, 16, 265-286

Goodchild, Michael F. (1986). Spatial Autocorrelation. Geo Books: Norwich, CT.

Head, Keith, and Thierry Mayer (2002) "Illusory Border Effects: Distance Mismeasurement Inflates Estimates of Home Bias in Trade,” Working Papers 2002-01, CEPII Research Center. Accessed in April 2012 at http://ideas.repec.org///phe156.html.

Hopcroft, Rosemary L. (1997) "Rural Organization and Receptive to Protectionism in Sixteenth Century Europe,” Journal for the Scientific Study of Religion, 36, 158-181.

Krugman, Paul. (1991a) "Increasing Returns and Economic Geography," Journal of Political Economy, 99, 183-199.

. (1991b) "Increasing Returns and Economic Geography,” Journal of Political Economy, 99, 483-499.

Lee, Lung-Fei and Jihai Yu. (2010) "Estimation of Spatial Autoregressive Panel Data Models with Fixed Effects,” Journal of Econometrics, 154, 165-185.

Linnemann, Hans. (1966) An Econometric Study of International Trade Flows. North-Holland: Amsterdam.

Martínez-Zarzoso, Inmaculada and Felicitas Nowak-Lehmann. (2003) "Augmented Gravity Model: An Empirical Application to Mercusur-European Union Trade Flows,” Journal of Applied Economics, 2, 269-294.

Mitchneck, Beth. (1995) "An Assessment of the Growing Local Economic Development Function of Local Authorities in Russia," Economic Geography, 71, 150-169.

Nisah, Christian, Chen Wu, and Walter. J. Mayer. (2012) “An Analysis of U.S. State’s Export Performance in the Asian Market," Annals of Regional Science, (forthcoming), Available online in April 2012 via http://www.springerlink.com/content/x4u2r7079518627w/.

Pöyhönen, Pentti. (1963) “A Tentative Model for the Volume of Trade between Countries,” Weltwirtschaftliches Archiv, 90, 93-100.

Rodrick, Dani, Arvind Subramanian, and Francesco Trebbi. (2002) "Institutions Rule: The Primacy of Institutions over Geography and Integration in Economic Development," NBER Working Paper \#9305. Accessed at in April 2012 http://ideas.repec.org/p/nbr/nberwo/9305.html.

Sachs, Jeffrey (2001) “Tropical Underdevelopment,” NBER Working Paper \#8119, Accessed in April 2012 via http://www.nber.org/papers/w8119.

Tinbergen, Jan (1962) Shaping the World Economy-Suggestions for an International Economic Policy. The Twentieth Century Fund: New York. 
Tobler, Waldo R. (1970) "A Computer Model Simulation of Urban Growth in the Detroit Region,” Economic Geography, 46, 234-240. 